\title{
PENGEMBANGAN KAMUS KOMPETENSI KESELAMATAN KERJA DI PT XYZ INDONESIA TBK
}

\author{
Yudhie Dwi Kristanto*)1, Idqan Fahmi ${ }^{* *}$, dan Agus Maulana ${ }^{* * *}$ \\ *) PT Holcim Indonesia \\ Jl Raya Narogong Km. 7 Cileungsi, Gunung Putri, Bogor 17310 \\ **) Sekolah Bisnis, Institut Pertanian Bogor \\ Jl. Raya Pajajaran, Bogor 16151 \\ ${ }^{* * *)}$ Universitas Dr Sutomo \\ Jl. Semmolowaru No. 84, Surabaya, Jawa Timur 6011
}

\begin{abstract}
The occupational health and safety known as K3 (Keselamatan dan kesehatan kerja) is one of the main objectives of PT XYZ Indonesia ltd. operation. Currently PT XYZ Indonesia ltd has possessed an occupational safety competent model for the operational area originally from XYZ global. The objectives of the research are to define the role of the Occupational safety and health (OSH) department, arrange an appropriate competent model and specify the competent level requirements in each job positions and also formulate a development program for each competency. The research uses DACUM (Developing a Curriculum) modified method and refers to AMA (American Management Association) competent literature. The result of the research shows that there are nine main competencies in the department of occupational safety. The four competencies in occupational safety cover 1) OHS mission implementation \& tactical planning, 2) controls hazards \& manages risks, 3) result oriented OHS, and 4) mastering complexity \& manages incidents. While the other five competencies are related to leadership competent, they are 1) communication, 2) partnering, 3) influencing, 4) building trust \& personal accountability, 5) critical \& analytical thinking. The content designed for the competent model are 1) the list of nine main required competencies, 2) the definition of each competency, 3) the level of each competency, 4) the development for each level, 5) the need of the competent level for each job positions. Based on the research, it shows that the DACUM modified method is suitable to formulate the competency needed from the unit.
\end{abstract}

Keywords: competent, occupational safety, human resources, DACUM, AMA

\begin{abstract}
ABSTRAK
Keselamatan dan kesehatan kerja, atau yang juga dikenal sebagai K3, merupakan salah satu tujuan utama dalam operasi PT XYZ Indonesia tbk. Saat ini PT XYZ Indonesia tbk telah memiliki model kompetensi keselamatan kerja untuk area operasional yang berasal dari XYZ global. Tujuan penelitian ini adalah merumuskan peranan-peranan departemen OHS, menyusun model kompetensi yang sesuai dan menentukan tingkat persyaratan kompetensi di masing-masing jabatan, serta merumuskan program pengembangan di setiap kompetensi. Penelitian ini menggunakan metode modified DACUM (Developing A Curriculum) dan merujuk kepada kamus kompetensi AMA (American Management Association). Hasil penelitian menunjukkan ada sembilan kompetensi utama untuk departemen keselamatan kerja. Empat dari sembilan kompetensi tersebut adalah kompetensi keselamatan kerja, yang meliputi 1) OHS mission implementation \& tactical planning, 2) controls hazards \& manages risks, 3) result oriented OHS, dan 4) mastering complexity \& manages incidents. Sebaliknya, lima kompetensi lainnya merupakan kompetensi leadership, yang meliputi 1) communication, 2) partnering, 3) influencing, 4) building trust \& personal accountability, 5) critical $\&$ analytical thinking. Isi dari model kompetensi yang dibuat adalah 1) daftar sembilan kompetensi utama yang dipersyaratkan, 2) definisi masing-masing kompetensi, 3) tingkatan masing-masing kompetensi, 4) pengembangan untuk setiap tingkatan, 5) kebutuhan tingkat kompetensi untuk setiap posisi jabatan. Dari penelitian juga terlihat bahwa metode modified DACUM dapat dipergunakan untuk merumuskan kompetensi yang dibutuhkan dari unit kerja ini.
\end{abstract}

Kata kunci: kompetensi, keselamatan kerja, sumber daya manusia, DACUM, AMA

\footnotetext{
${ }^{1}$ Alamat Korespondensi:

Email: yudhiedeka@gmail.com
} 


\section{PENDAHULUAN}

PT XYZ Indonesia tbk merupakan bagian dari grup semen internasional XYZ group, dengan produk utama berupa semen, batu pecah (agregat) dan beton. Salah satu kepedulian utama XYZ dalam operasi perusahaannya adalah kepedulian dalam aspek keselamatan kerja. Untuk meningkatkan kinerja dalam keselamatan kerja maka XYZ pusat telah menerbitkan empat kompetensi utama di bidang keselamatan kerja, yang dikenal sebagai kompetensi OHS. Kompetensi OHS ini mulai diberlakukan di PT XYZ Indonesia tbk pada tahun 2014, dan akan berlaku secara penuh pada tahun 2015. Namun, kompetensi OHS ini berlaku wajib hanya bagi line operational, selaku pihak yang mengoperasikan peralatan dan proses di area kerja PT XYZ Indonesia tbk. Tidak ada petunjuk mengenai kompetensi OHS yang dibutuhkan oleh departemen Corporate OHS sendiri, selaku pembina dalam pelaksanaan K3 di PT XYZ Indonesia.

Tantangan lain yang dihadapi oleh departemen Corporate OHS adalah terjadinya perombakan organisasi di dalam PT XYZ Indonesia tbk. Perubahan struktur yang dilakukan mengakibatkan departemen OHS hanya berfungsi sebagai korporasi saja, sementara OHS site akan lebih berfungsi di aspek operasional. Saat ini telah ditetapkan fungsi utama dari Departemen Corporate OHS oleh XYZ pusat yang meliputi pengembangan sistem keselamatan kerja, penyedia pelatihan keselamatan kerja, dan audit terhadap sistem keselamatan kerja. Namun, peran yang ditetapkan tersebut hanya berupa peran secara umum. Detail dari masing-masing peran, terutama terkait sistem keselamatan kerja yang dipergunakan oleh PT XYZ Indonesia tbk belum teridentifikasi dengan detil.

Perubahan organisasi, perubahan fungsi serta daftar kebutuhan kompetensi yang belum tersedia dari departemen Corporate OHS akan menjadi tantangan tersendiri dalam penerapan keselamatan kerja di PT XYZIndonesiatbk. MenurutDubois(2004), manajemen sumber daya manusia yang berbasis kompetensi akan dapat merangsang karyawan untuk meningkatkan kinerja mereka. Oleh sebab itu, diperlukan suatu model kompetensi untuk departemen Corporate OHS untuk meningkatkan kinerjanya. Berdasarkan uraian tersebut maka penelitian ini bertujuan 1) merumuskan perananperanan baru dari departemen Corporate OHS PT XYZ Indonesia tbk berdasarkan sistem keselamatan kerja yang dianut PT XYZ; 2) membuat model kompetensi yang sesuai dengan peranan-peranan baru departemen Corporate OHS PT XYZ Indonesia tbk; 3) menyusun program keahlian yang menunjang pembentukan kompetensi sesuai model kompetensi untuk departemen Corporate OHS PT XYZ Indonesia tbk.

Penelitian ini diharapkan dapat diterapkan di departemen Corporate OHS untuk meningkatkan kinerjanya. Selain itu metodologi yang dipergunakan juga diharapkan dapat diterapkan ke unit kerja lainnya sehingga dapat meningkatkan kinerja perusahaan secara keseluruhan.

Berikut disajikan tinjauan penelitian terdahulu yang terkait dengan penelitian yang dilakukan. Kompetensi dapat diartikan sebagai sebuah paket pengetahuan, keahlian dan nilai-nilai yang diperlukan oleh seorang individu dalam menjalankan pekerjaannya dengan baik, untuk saat ini maupun untuk masa mendatang (Ulrich, 2009). Menurut Dubois (2004), fungsi kompetensi terkait aktivitas sumber daya manusia meliputi tahap perekrutan awal, penilaian kinerja hingga sebagai panduan dalam pengembangan karyawan.Penelitian Dar (2011), menunjukkan bahwa mengembangkan sumber daya manusia merupakan salah satu strategi yang penting dalam menciptakan keunggulan bersaing.. Dari penelitian Fabio (2016) terlihat bahwa komitmen organisasi sangat berpengaruh terhadap kinerja karyawan. Penelitian Marchington (2003) menunjukkan bahwa kestabilan dalam sumber daya manusia merupakan kunci daya saing dalam perusahaan. Hal ini diperkuat oleh penelitian DeSarbo (2007), Gilgieous (2001) dan Khandekar (2005), yang juga menemukan kesimpulan sama, bahwa sumber daya manusia merupakan komponen penting dalam menciptakan keunggulan bersaing. Dalam penelitian Gupta (2012), terlihat bahwa strategi diferensiasi perusahaan tidak akan tersampaikan ke konsumen apabila tidak didukung oleh karyawannya.

Perusahaan harus membina pengetahuan dan keahlian orang di dalamnya agar selalu kompetitif (Sharkie, 2003). Dari penelitian Ponanake (2014) terlihat bahwa kompetensi merupakan salah satu strategi strategi yang dapat dipergunakan untuk menghadapi perubahan faktor eksternal. Hal ini sejalan dengan penelitian Foon (2009) tentang membangun kompetensi yang dapat memenuhi harapan konsumen di masa mendatang.

Dubois (2004) menjelaskan beberapa metode-metode yang dapat digunakan dalam mengidentifikasi dan membangun kompetensi inti, yaitu job competence 
assessment method, competency menu methods dan modified DACUM(Developing A Curriculum) method. Metode modified DACUM tersebut menggunakan panel tim ahli dalam merumuskan kompetensi yang dibutuhkan. Tim panel ahli ini terdiri dari para praktisi terkait dalam bidang yang dibahas dan juga klien dari unit tersebut. Tahap pertama dari metode ini adalah memetakan seluruh aktivitas dari unit yang dianalisis, kemudian tahap selanjutnya adalah mengidentifikasi semua kompetensi yang dibutuhkan terhadap aktivitas tersebut sehingga tersusun sebuah model kompetensi yang sesuai.

Yang et al. (2006) telah melakukan penelitian terkait metode-metode penyusunan model kompetensi yang dikemukakan oleh Dubois (2004). Menurutnya proses pembuatan model kompetensi berdasarkan aktivitas memiliki keunggulan berupa tingkat kesepakatan terhadap model yang dibangun cukup tinggi dan hubungan antara keunggulan kompetitif perusahaan dengan kompetensi individu dapat terjabarkan dengan jelas. Menurut penelitian Muslera et al. (2012), metode berbasis aktivitas memang cukup kompleks. Namun, sangat sesuai untuk unit kecil dalam sebuah organisasi. Penelitian Muslera et al. (2012) juga menunjukkan bahwa pendekatan orientasi bisnis, seperti yang digunakan oleh Yang, sangat sesuai untuk mengidentifikasi kompetensi. Lebih lanjut, dalam penelitian Shippmann (2000), menunjukkan bahwa perlunya keterlibatan narasumber ahli dalam proses penyusunan kompetensi ini. Berdasarkan penelitian tersebut maka metode yang paling sesuai adalah metode penyusunan kompetensi yang berbasis aktivitas (DACUM).

Penelitian Ey (2006) menunjukkan perlunya hirarki atau tingkatan pada masing-masing kelompok pada sebuah model kompetensi. Pada penelitian Trathen (2007), ditemukan bahwa pembinaan dan pelatihan memiliki peranan penting dalam kompetensi. Oleh sebab itu, didalam sebuah matriks kompetensi ini harus juga mencakup tentang pelatihan dan pengembangan. Penelitian Goel (2010) menyatakan apabila perusahaan memiliki model kompetensi yang tepat maka akan memudahkan perusahaan untuk membina dan mengembangkan karyawannya. Selain itu model kompetensi yang dibangun dengan tepat akan dapat menjabarkan hubungan antara strategi perusahaan dengan program pelatihan untuk karyawan sesuai dengan model kompetensi. Jadi, kinerja perusahaan dapat meningkat (Gangani, 2006).
Ljungquist (2007) dalam penelitiannya menyatakan bahwa kapabilitas juga merupakan bagian dari sebuah kompetensi. Kapabilitas ini menunjukkan kemampuan aktual dari seseorang yang menunjukkan tingkat kompetensinya. Hal ini sejalan dengan McShane (2010) yang mendefinisikan perilaku sebagai akibat dari dorongan motivasi, kemampuan dan pemahaman terhadap peran dari seorang individu ketika dihadapkan kepada situasi tertentu. Hal ini sejalan dengan penelitian Bashook (2005), yang juga merekomendasikan bukti (evidence) perilaku sebagai alat untuk menilai kompetensi, menjadi bagian dari model yang dibangun.

\section{METODE PENELITIAN}

Penelitian ini dilakukan di PT XYZ Indonesia tbk yang berlokasi di Jawa Barat. Penelitian dilakukan selama 4 bulan, yaitu bulan July 2015 - Oktober 2015. Pemilihan lokasi penelitian ini berdasarkan lokasi departemen OHS, yang berada di pabrik Jawa Barat. Selain itu semua unit kerja yang memiliki risiko tinggi, yang juga merupakan klien dari departemen ini, memiliki perwakilan di pabrik Jawa Barat. Jadi, data yang diambil dari area tersebut dapat mewakili kondisi keseluruhan dari PT XYZ Indonesia tbk. Oleh sebab itu, ruang lingkup penelitian ini dibatasi pada area pabrik Jawa Barat.

Departemen Corporate OHS ini memiliki kondisi dimana tidak semua posisi jabatan terisi, dan juga telah terjadi perubahan peran yang menyebabkan sulitnya pendefinisian kompetensi berdasarkan kinerja yang lampau. Oleh sebab itu, hipotesis dari penelitian ini adalah metode modified DACUM dapat dipergunakan untuk merumuskan kompetensi dari departemen tersebut, dengan segala kondisi yang ada saat ini.

Desain penelitian ini menggunakan metode kualitatif melalui eksplorasi dengan menggunakan teknik in depth interview secara purposive sampling dengan responden terpilih. Responden dipilih dari unit kerja yang memiliki risiko keselamatan paling tinggi. Sebagai narasumber yang mewakili departemen tersebut, akan dipilih karyawan di tingkat manajemen tengah atau senior yang pernah terlibat mendalam dengan proyek-proyek terkait keselamatan kerja. Diharapkan narasumber ini dapat memberikan informasi yang mewakili kebutuhan unit kerjanya sekaligus memberikan gambaran detail dari aktivitas keselamatan kerja yang dilakukan di 
unitnya. Jumlah narasumber yang dilibatkan dalam penelitian ini adalah sembilan orang, mewakili semua unit yang terlibat.

Analisis DACUM yang digunakan dalam penelitian ini akan memperbandingkan antara perilaku harapan dari masing-masing aktivitas di departemen Corporate OHS dengan indikator perilaku dari kamus kompetensi yang dijadikan referensi. Berdasarkan perbandingan tersebut akan diketahui kompetensi-kompetensi yang paling diperlukan dari departemen Corporate OHS.

Kerangka penelitian diawali dengan menggali visi, misi dan kebijakan K3 perusahaan ke dalam tanggung jawab dari departemen Corporate OHS. Kemudian tanggung jawab tersebut diuraikan hingga menjadi aktivitas detail dari departemen berdasarkan kebutuhan dari sistem K3 yang dijalankan oleh perusahaan. Aktivitas-aktivitas inilah yang kemudian dirumuskan kondisi idealnya berdasarkan kebutuhan dari responden ahli. Kebutuhan pelanggan inilah yang akan digunakan sebagai rujukan dalam menyusun kompetensi yang dibutuhkan berdasarkan menu kompetensi dari kamus AMA (American Management Association) (Tobin, 2008). Kompetensi yang telah disusun kemudian diadaptasi agar sesuai dengan kebutuhan PT XYZ Indonesia tbk, dan kemudian ditentukan pula persyaratan kebutuhan untuk setiap posisi jabatan serta program pengembangan yang sesuai.

\section{HASIL}

\section{Eksplorasi Visi dan Misi PT XYZ Indonesia tbk}

Visi dari XYZ Indonesia adalah "Building sustainable solutions for society's future" (Membangun solusi berkelanjutan bagi masyarakat di masa mendatang).
Visi ini diwujudkan melalui tiga misi perusahaan, yaitu delivering sustainable building solutions focused on distinctive customer segments, caring for safety and environment, through the development of people, innovative leadership and integrated networks.

Apabila dilihat dari sudut pandang keselamatan kerja maka terlihat jelas bahwa keselamatan kerja merupakan salah satu prioritas utama perusahaan yang tertuang dalam misi ke-tiganya. Lebih lanjut dilakukan wawancara dengan tim ahli untuk menggali tanggung jawab departemen Corporate OHS terhadap misi perusahaan. Hasilnya dapat dilihat dalam Tabel 1.

\section{Perumusan Peran Departemen Corporate OHS}

Peran sebelumnya dari departemen ini melingkupi peran sebagai penegak K3 di lapangan sekaligus sebagai regulator dari K3. Namun, pada 2015 terjadi pemisahan tugas. Tugas penegak K3 di lapangan diberikan kepada departemen OHS lapangan, sementara peran departemen Corporate OHS difokuskan kepada fungsi regulator sentral. Oleh sebab itu, analisis berikutnya adalah mempelajari secara detil dari masing-masing tanggung jawab tersebut, melalui pengolahan data sekunderterhadap semua sistem $\mathrm{K} 3$, undang-undang dan panduan terkait K3 yang digunakan oleh perusahaan. Uraian peran dari departemen OHS berdasarkan semua data sekunder tersebut kemudian di validasi melalui diskusi dengan nara sumber. Peran tambahan diluar dari data sekunder juga ditambahkan pada daftar peran tersebut. Beberapa uraian peran dari sumber yang berbeda-beda tersebut memiliki beberapa kesamaan. Tahap selanjutnya adalah mengelompokkan peran tersebut berdasarkan kesamaan sehingga diperoleh delapan peran dari departemen Corporate OHS. Hasil ini kemudian di hubungkan dengan tiga peran utama sesuai arahan dari global, seperti terlihat pada Tabel 2.

Tabel 1. Eksplorasi misi

\begin{tabular}{|c|c|}
\hline Misi & Tindak Lanjut dari Departemen OHS \\
\hline $\begin{array}{l}\text { Delivering sustainable } \\
\text { building solutions focused on } \\
\text { distinctive customer segments }\end{array}$ & $\begin{array}{l}\text { - Memberi masukan kepada line function dalam proses bisnis, untuk memastikan proses } \\
\text { bisnis mereka dalam menciptakan nilai bagi konsumen dapat berjalan dengan aman }\end{array}$ \\
\hline $\begin{array}{l}\text { Caring for safety and } \\
\text { environment }\end{array}$ & $\begin{array}{l}\text { - Memenuhi semua peraturan terkait K3 berdasarkan undang-undang } \\
\text { - Memenuhi semua standar keselamatan kerja terkait dengan industri ini } \\
\text { - Memenuhi semua standar keselamatan kerja yang ditetapkan oleh group XYZ dunia } \\
\text { - Melakukan semua upaya yang memungkinkan untuk mengurangi risiko kerja }\end{array}$ \\
\hline $\begin{array}{l}\text { Through the development of } \\
\text { people, innovative leadership } \\
\text { and integrated networks }\end{array}$ & $\begin{array}{l}\text { - Menyediakan dan memfasilitasi pengembangan dan pelatihan terkait K3 untuk semua } \\
\text { karyawan } \\
\text { - Secara rutin mencari dan mempelajari praktek-praktek terbaik dalam menerapkan K3 } \\
\text { dan semua potensi bahaya dari industri sejenis dari sumber eksternal }\end{array}$ \\
\hline
\end{tabular}


Tabel 2. Uraian peran dari departemen Corporate OHS

\begin{tabular}{ll}
\hline \multicolumn{1}{c}{ Peran utama departemen OHS } & \multicolumn{1}{c}{ Peran detail OHS } \\
\hline System development & Pengembangan Sistem K3 \\
& Pengembangan Sistem Kendali Risiko \\
& Pengembangan Tanggap Darurat \\
Trainer & Komunikasi K3 \\
& Pengembangan Pengetahuan K3 Bagi Area Operasional \\
Auditor & Meningkatkan Efektifitas Sistem dan Audit \\
& Manajemen Insiden \\
& Dokumentasi K3 \\
\hline
\end{tabular}

\section{Analisis Aktivitas dari Departemen OHS}

Analisis dilakukan dengan menggunakan metode business process Mapping melalui analisis input proses - output dari kedelapan peran tersebut. Analisis dilakukan bersama dengan narasumber ahli dari departemen OHS. Serangkaian aktivitas hasil analisis tersebut dikelompok-kelompokkan berdasarkan kesamaan jenis aktivitas. Oleh karena itu, dapat terlihat aktivitas apa saja yang dilakukan oleh departemen ini untuk memenuhi perannya. Aktivitas tersebut adalah melakukan Review aturan terkait K3, melakukan penilaian kinerja K3 internal, identifikasi faktor kontributor $\mathrm{K} 3$, penentuan target kinerja, komunikasi terkait $\mathrm{K} 3$, fasilitator bagi line function, penyusunan prosedur dan program $\mathrm{K} 3$, pendampingan bagi line function, progress review dan reporting, mencari referensi eksternal, serta mempersiapkan sumber daya untuk penerapan K3. Aktivitas-aktivitas inilah yang akan menjadi landasan untuk mengidentifikasi keinginan pelanggan.

\section{Faktor Sukses Keberhasilan dari Masing-masing Aktivitas}

Untuk menentukan kompetensi yang dibutuhkan maka perlu dilakukan pencocokan antara perilaku berdasarkan kamus kompetensi dengan perilaku yang diharapkan timbul dalam aktivitas sehari-hari. Perilaku yang diharapkan timbul tersebut adalah perilaku ideal yang diharapkan oleh pelanggan. Oleh sebab itu, kita perlu menanyakan kepada responden yang mewakili pelanggan mengenai perilaku harapan tersebut. Responden yang dipilih untuk mewakili pelanggan adalah responden yang memiliki pemahaman cukup baik mengenai pembagian tugas dan tanggung jawab antara line function dengan departemen OHS. Karena tidak diharapkan terjadi kondisi bertumpuk (overlapping) antara tugas kedua fungsi tersebut. Selain itu responden juga harus berasal dari fungsi bisnis utama (core process) dari PT XYZ Indonesia. Karena pada fungsi utama inilah tempat tejadinya proses aktivitas berisiko tinggi yang sering berkontribusi terhadap kecelakaan kerja. Untuk memastikan responden benar-benar memahami aktivitas bisnis dari areanya maka responden harus memiliki pengalaman kerja sekurangnya 5 tahun dan memiliki jabatan sekurang-kurangnya di level manajemen menengah.

Hasil wawancara dengan responden terpilih tersebut kemudian digabung dan dikelompokkan berdasarkan masing-masing aktivitas. Contoh dari sebagian harapan pelanggan pada Tabel 3 .

\section{Analisis Kompetensi Berdasarkan Kamus Kompetensi}

Tahap selanjutnya adalah dilakukan analisis mengenai kompetensi yang diharapkan berdasarkan kesamaan perilaku. Perilaku atau behavior merupakan sesuatu tindakan yang terlihat dan terukur sehingga masingmasing perilaku inilah yang akan dicocokkan dengan perilaku rujukan dari kamus kompetensi. Kamus kompetensi yang dijadikan rujukan adalah kamus kompetensi dari AMA. Kamus ini memiliki satu dimensi perilaku. Ini serupa dengan model kompetensi XYZ yang juga menggunakan satu dimensi. Sehingga diharapkan kompatibel untuk diadopsi dalam perumusan kompetensi ini.

Kamus kompetensi AMA mendefinisikan tiga jenis kompetensi, yaitu "managing business", "managing others" dan "managing self". Masing-masing kompetensi dalam kamus AMA memiliki indikator perilakunya masing-masing, mulai dari level yang terendah sampai dengan level yang tertinggi. Masingmasing perilaku rujukan akan diperbandingkan dengan perilaku harapan pelanggan. Dengan 
memperbandingkan hal tersebut maka akan diketahui kompetensi apa yang diharapkan dan pada level berapa. Contoh perbandingan tersebut pada Tabel 4.

Dalam analisis ini akan dicatat jenis kompetensi apa yang diharapkan, seberapa sering kompetensi itu terlihat saat memperbandingkan perilaku (frekuensi) serta seberapa besar tingkat level yang diharapkan (range). Dalam range ini akan dicatat juga level terendah yang terlihat (min) dan level tertinggi yang terlihat (max). Kemudian rentang antara min dan max tersebut akan dibandingkan dengan skala keseluruhan, untuk mengetahui seberapa besar span yang terlihat. Rangkuman kompetensi yang terlihat ini dapat dilihat pada Tabel 5 .

\section{Penyusunan Model Kompetensi}

Dari analisis terlihat ada 43 kompetensi yang diharapkan dari departemen OHS. Namun, jumlah tersebut terlalu banyak untuk diaplikasikan. Berdasarkan hasil diskusi dengan narasumberahli di Human Resources (HR) maka disepakati untuk memilih Sembilan kompetensi yang paling utama bagi departemen OHS. Dalam memilih Sembilan kompetensi utama, juga dipertimbangkan bahwa kompetensi yang paling berdampak langsung terhadap kinerja departemen OHS adalah kompetensi yang terkait dengan managing business sehingga disepakati oleh tim ahli bahwa sekurangnya separuh dari Sembilan kompetensi tersebut harus merupakan managing business. Sehingga didapat bahwa empat kompetensi merupakan kompetensi managing business, sedangkan lima sisanya merupakan kompetensi managing others dan managing self. Proses pemilihan dilakukan dengan menggunakan metode pairwise comparison, dengan tim ahli dari Corporate OHS. Rangkuman hasil ditunjukkan pada Tabel 6.

Kompetensi yang dipilih kemudian diadaptasi agar sesuai dengan kebutuhan departemen. Proses adaptasi model kompetensi untuk kompetensi OHS ini dilakukan dengan mempertimbangkan kompetensi OHS untuk line function, yang terlebih dahulu disediakan oleh global. Hasil pemilihan dan adaptasi kompetensi utama tersebut dirangkum dalam Tabel 7.

Tabel 3. Contoh perilaku harapan dari departemen OHS

\begin{tabular}{cc}
\hline Aktivitas kunci & Perilaku harapan \\
\hline Review aturan & - Dilakukan dengan lengkap (melingkupi seluruh bisnis dari line function); Mencakup seluruh \\
& kegiatan K3 di site; Sejalan dengan bisnis; Sejalan dengan program-program terkait OHS \\
& - Dilakukan setiap tahun; Selalu up to date; Selalu aktif mengupdate informasi \\
& - Melibatkan line function sehingga mengakomodir masukan dari line \\
& - Ada forum komunikasi resmi dengan line function; Dikomunikasikan ke line function \\
& - Meluruskan dan memilihkan apa yang aplikabel bagi line; Memudahkan bagi line function \\
& - Dibuatkan step by step/roadmap implementasinya \\
& - Berperan sebagai expert dan trainer terkait peraturan-peraturan tersebut \\
\hline
\end{tabular}

Tabel 4. Contoh proses identifikasi kompetensi

\begin{tabular}{cll}
\hline Aktivitas kunci & \multicolumn{1}{c}{ Kondisi harapan } & \multicolumn{1}{c}{$\begin{array}{c}\text { Kesesuaian kompetensi } \\
\text { berdasarkan kamus kompetensi AMA }\end{array}$} \\
\hline Review aturan & - Mencakup seluruh kegiatan K3 di site & - Customer focus (Level 7) \\
& - Selalu aktif mengupdate informasi & - Problem solving (Level 3) \\
& - Melibatkan line functiondan mengakomodir & - Time management (Level 3) \\
& masukan & - Valuing diversity (Level 4) \\
& - Meluruskan dan memilihkan apa yang aplikabel & - Building teams (Level 6) \\
bagi line; Memudahkan bagi line function & - Networking (Level 2) \\
& & - Partnering (Level 4) \\
& - Building relationship (Level 4)
\end{tabular}


Tabel 5. Kompetensi managing business, managing others yang timbul

\begin{tabular}{|c|c|c|c|c|c|}
\hline \multirow{2}{*}{ Competency } & \multicolumn{2}{|c|}{ Range } & \multirow{2}{*}{ Skala } & \multirow{2}{*}{$\operatorname{Span}(\%)$} & \multirow{2}{*}{ Freq } \\
\hline & Min & Max & & & \\
\hline \multicolumn{6}{|l|}{ Managing Business } \\
\hline Operational \& tactical planning & 1 & 8 & 8 & 100 & 19 \\
\hline Problem solving & 1 & 4 & 4 & 100 & 18 \\
\hline Result orientation & 2 & 6 & 9 & 56 & 15 \\
\hline Quality orientation & 2 & 6 & 7 & 71 & 13 \\
\hline Mastering complexity & 1 & 4 & 5 & 80 & 12 \\
\hline Customer focus & 2 & 7 & 13 & 46 & 10 \\
\hline Driving innovation & 2 & 7 & 8 & 75 & 8 \\
\hline Monitoring the external environment & 1 & 3 & 4 & 75 & 7 \\
\hline Managing \& leading change & 1 & 9 & 11 & 82 & 6 \\
\hline Core functional / technical skills & 4 & 4 & 5 & 20 & 5 \\
\hline Strategic planning & 1 & 5 & 11 & 45 & 5 \\
\hline Business \& financial acumen & 3 & 3 & 9 & 11 & 3 \\
\hline Decision making & 2 & 2 & 6 & 17 & 2 \\
\hline Global perspective & 1 & 4 & 6 & 67 & 2 \\
\hline Organizational savy & 1 & 3 & 8 & 38 & 2 \\
\hline Resource management & 2 & 4 & 6 & 50 & 2 \\
\hline Strategic thinking & 1 & 2 & 7 & 29 & 2 \\
\hline Human resources planning & 4 & 4 & 5 & 20 & 1 \\
\hline \multicolumn{6}{|l|}{ Managing Others } \\
\hline Oral communication & 1 & 8 & 9 & 89 & 12 \\
\hline Partnering & 2 & 4 & 7 & 43 & 12 \\
\hline Managing conflict & 1 & 5 & 8 & 63 & 8 \\
\hline Building teams & 1 & 7 & 9 & 78 & 7 \\
\hline Empowering other & 1 & 4 & 7 & 57 & 7 \\
\hline Influencing & 1 & 7 & 8 & 88 & 7 \\
\hline Building relationship & 1 & 5 & 6 & 83 & 6 \\
\hline Managing people for performance & 1 & 5 & 9 & 56 & 6 \\
\hline Written communication & 1 & 6 & 8 & 75 & 6 \\
\hline Clarifying roles \& accountabilities & 4 & 7 & 8 & 50 & 5 \\
\hline Networking & 1 & 5 & 6 & 83 & 5 \\
\hline Delegating & 2 & 2 & 7 & 14 & 3 \\
\hline Emotional intelligence / interpersonal savy & 2 & 7 & 9 & 67 & 3 \\
\hline Coaching & 1 & 2 & 9 & 22 & 2 \\
\hline Valuing diversity & 2 & 4 & 10 & 30 & 2 \\
\hline Motivating others & 6 & 6 & 9 & 11 & 1 \\
\hline \multicolumn{6}{|l|}{ Managing Self } \\
\hline Building trust \& personal accountability & 1 & 6 & 11 & 55 & 9 \\
\hline Critical \& analytical thinking & 2 & 6 & 7 & 71 & 5 \\
\hline Emotional intelligence / self-awareness & 1 & 4 & 8 & 50 & 4 \\
\hline Flexibility \& agility & 2 & 3 & 10 & 20 & 4 \\
\hline Resilience \& stress tolerance & 2 & 6 & 10 & 50 & 4 \\
\hline Creative thinking & 2 & 3 & 7 & 29 & 3 \\
\hline Time management & 2 & 4 & 11 & 27 & 3 \\
\hline Action orientation & 3 & 8 & 10 & 60 & 2 \\
\hline Self confidence & 2 & 5 & 8 & 50 & 2 \\
\hline
\end{tabular}


Tabel 5. Kompetensi managing business, managing others yang timbul, dan managing self

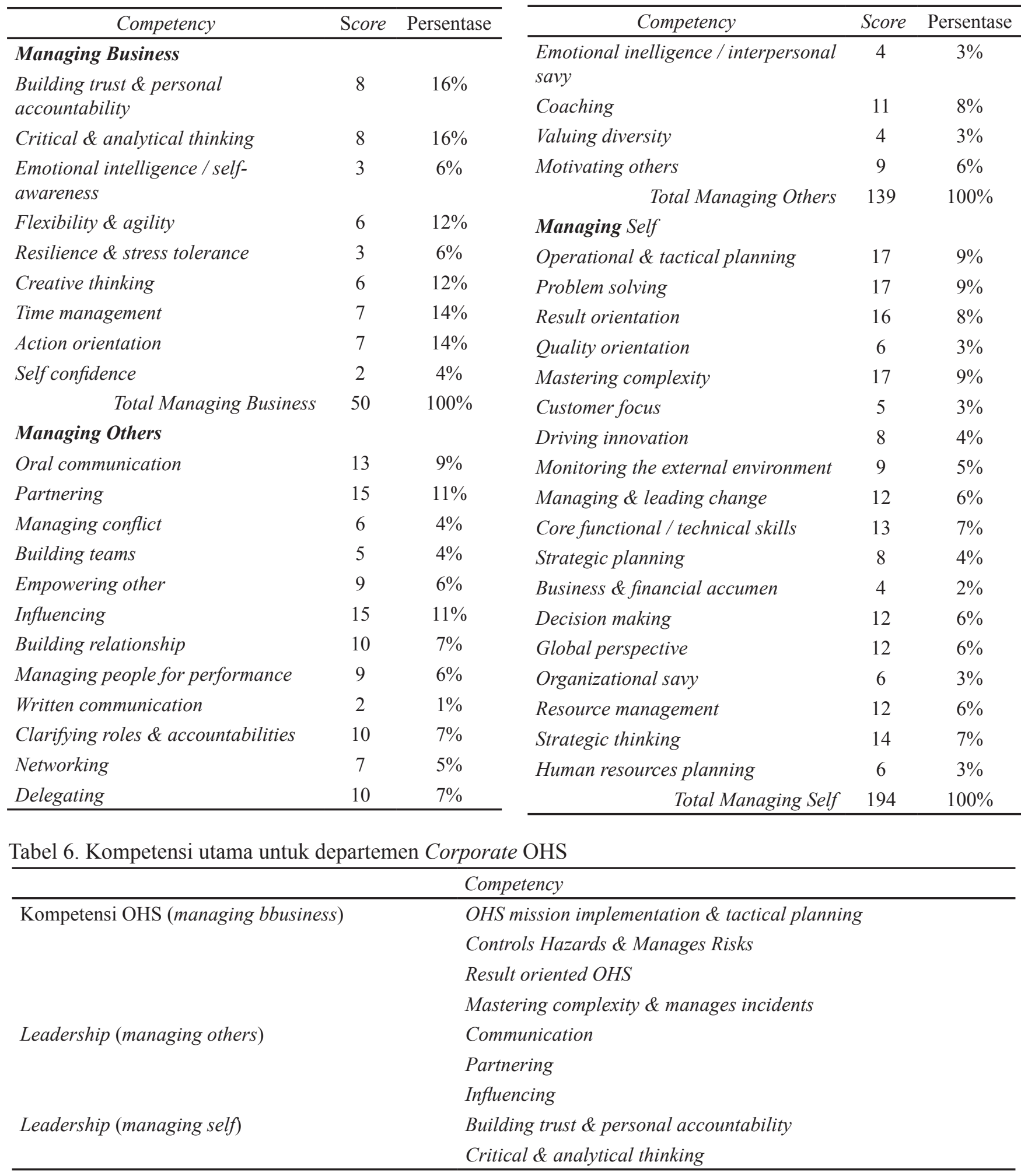

Penyesuaian selanjutnya dari model yang dibangun adalah penyesuaian definisi kompetensi dan level kompetensi. Pada model kompetensi AMA level kompetensi yang tersedia cukup bervariasi, mulai dari 4 level sampai dengan 11 level. Sementara di PT. XYZ sebelumnya hanya menggunakan 5 level. Oleh sebab itu, perlu dilakukanlah penyamaan tingkatan. Selain itu juga perlu dilakukan penyesuaian kriteria indikator perilaku di masing-masing tingkat kompetensi. Dengan perubahan level kompetensi menjadi 5 maka secara otomatis level indikator perilaku juga akan terpengaruh. Selain itu penyesuaian ini juga untuk mengakomodir konsep nilai PT. XYZ dan juga bisnis yang spesifik dibidang K3. Berikut adalah contoh dari adaptasi yang dilakukan: 
Kompetensi: OHS mission implementation \& tactical planning

Definisi :

Menentukantujuan OHSjangkapendek dan menetapkan langkah-langkah untuk mencapainya; menentukan bagaimana cara untuk memanfaatkan personel, peralatan, fasilitas dan sumber daya lainnya secara efisien untuk mencapai tujuan proyek atau inisiatif terkait $\mathrm{K} 3$; mengatur penjadwalan dan koordinasi aktivitas antar individu, tim maupun unit

Level :

1. Memahami perumusan rencana K3 yang realistis berdasarkan panduan dari global.

2. Memahami peran lapangan dan pihak diluar OHS didalam perusahaan.

3. Mampu membuat metode dan sistem untuk memeriksa, mengendalikan dan menjalankan diskusi kinerja.

4. Mampu melibatkan line function dalam perencanaan dan penentuan prioritas dari proyek atau inisiatif K3.

5. Mampu melakukan evaluasi proses implementasi K3 saat ini.

Hasil dari tahap ini adalah sebuah kamus kompetensi yang sesuai dengan Corporate OHS. Kamus ini berisi tentang nama-nama kompetensi utama yang harus dimiliki oleh departemen Corporate OHS, definisi dari masing-masing kompetensi yang sesuai dengan konteks bisnis OHS dan panduan perilaku di XYZ Indonesia, dan lima level indikator perilaku untuk masing-masing kompetensi tersebut.

\section{Penentuan Tingkat Kompetensi di Masing-Masing Jabatan}

Setelah kamus kompetensi disusun dan diadaptasi terhadap PT XYZ Indonesia maka langkah selanjutnya adalah menentukan tingkat kompetensi bagi masingmasing posisi di departemen OHS. Penentuan ini dilakukan melalui triangulasi data dari tiga narasumber yang kemudian di rata-rata untuk menentukan gabungannya, dengan bobot perata-rataan terbesar pada pendapat kepala departemen. Saat ini ada lima posisi jabatan di departemen Corporate OHS. Beberapa posisi tersebut masih lowong, dan akan dilakukan perekrutan karyawan di posisi tersebut. Oleh sebab itu, panduan kompetensi ini dapat dipergunakan dalam proses rekrutmen tersebut. Hasil dari penentuan persyaratan level kompetensi di masing-masing jabatan disajikan dalam Tabel 7.

\section{Penyusunan Pelatihan dan Pengembangan Kompetensi OHS}

Dalam penelitian ini aspek pengembangan yang dibahas secara mendalam adalah pengembangan yang terkait dengan kompetensi OHS, karena memang belum ada panduannya. Mengenai pengembangan kompetensi di area kompetensi leadership telah dibuat oleh PT XYZ Indonesia. Proses pengembangan ini menggunakan metode training hanya untuk pemahaman di tingkat pertama dan kedua. Pada level yang lebih tinggi pengembangan dilakukan menggunakan pendekatan praktek atau penugasan. Contoh ringkasan dari panduan pengembangan untuk kompetensi OHS dapat dilihat di Tabel 8.

Tabel 7. Tingkat kompetensi untuk setiap posisi di departemen OHS

\begin{tabular}{lccccc}
\hline \multicolumn{1}{c}{ Kompetensi } & $\begin{array}{c}\text { OHS } \\
\text { Manager }\end{array}$ & $\begin{array}{c}\text { OHS } \\
\text { Training }\end{array}$ & $\begin{array}{c}\text { OHS System } \\
\text { Development }\end{array}$ & $\begin{array}{c}\text { OHS } \\
\text { Auditor }\end{array}$ & $\begin{array}{c}\text { OHS } \\
\text { Compliance }\end{array}$ \\
\hline OHS mission implementation \& tactical planning & 5 & 2 & 5 & 4 & 4 \\
Controls hazards \& manages risks & 5 & 5 & 3 & 5 & 4 \\
Result oriented OHS & 5 & 3 & 4 & 5 & 4 \\
Mastering complexity \& manages incidents & 4 & 2 & 5 & 4 & 4 \\
Communication & 4 & 5 & 3 & 4 & 4 \\
Partnering & 4 & 3 & 5 & 4 & 4 \\
Influencing & 5 & 5 & 3 & 4 & 4 \\
Building trust \& personal accountability & 5 & 2 & 3 & 4 & 5 \\
Critical \& analytical thinking & 3 & 3 & 5 & 3 & 3 \\
\hline
\end{tabular}


Tabel 8. Contoh panduan pengembangan kompetensi

\begin{tabular}{ll}
\hline \multicolumn{1}{c}{ OHS mission implementation \& tactical planning } \\
\hline Knowledge & Pelatihan mengenai visi dan misi OHS global, regional dan lokal \\
Comprehension & Pelatihan mengenai manajemen proyek (non-konstruksi) \\
Practitioner & On job training (OJT) terkait sosialisasi dan implementasi misi/program/inisiatif OHS di lapangan \\
Advanced & OJT sebagai project manager dalam proyek strategis OHS \\
Expert & OJT dalam penyusunan roadmap OHS lokal, sebagai penjabaran dari roadmap global \\
\hline
\end{tabular}

\section{Implikasi Manjerial}

Isi dari kamus kompetensi yang dibangun dalam penelitian ini meliputi daftar kompetensi utama, definisi dan tingkatan masing-masing kompetensi, pengembangan untuk setiap tingkatan, dan kebutuhan kompetensi untuk setiap posisi jabatan di departemen Corporate OHS. Untuk penerapan dari hasil penelitian ini maka diperlukan langkah-langkah lebih lanjut yang mengintegrasikan kamus yang dibangun kedalam aspek operasional dari departemen bersangkutan. Langkah-langkah tersebut adalah memasukkan standar kebutuhan kompetensi kedalam deskripsi pekerjaan di setiapjabatan di departemen OHS. Menggunakan kamus yang dibangun sebagai acuan saat proses penilaian kinerja dan perekrutan karyawan di unit kerja tersebut. Serta menggunakan matrik pengembangan berdasarkan kamus tersebut, sebagai acuan dari program pelatihan anggota tim.

\section{KESIMPULAN DAN SARAN}

\section{Kesimpulan}

Hasil identifikasi peran dari departemen OHS berdasarkan aturan perundangan yang berlaku dan panduan terkait K3 menghasilkan delapan peran baru. Peran-peran tersebut adalah pengembangan sistem K3, pengembangan sistem kendali risiko, pengembangan tanggap darurat, komunikasi $\mathrm{K} 3$, pengembangan pengetahuan K3 bagi area operasional, meningkatkan efektifitas sistem dan audit, manajemen insiden dan dokumentasi K3. Peran tersebut lalu dianalisis lebih lanjut menggunakan metode business process mapping dan menghasilkan uraian 11 aktivitas utama yang dilakukan oleh departemen OHS dalam rangka memenuhi perannya.

Hasil metode modified DACUM dapat dipergunakan dalam merumuskan kompetensi dari departemen OHS. Ditemukan bahwa ada Sembilan kompetensi utamayang dibutuhkanolehdepartementersebut. Empatkompetensi
OHS tersebut meliputi "OHS mission implementation \& tactical planning", "controls hazards \& manages risks", "result oriented OHS", dan "mastering complexity \& manages incidents". Sedangkan 5 kompetensi leadership meliputi "communication", "partnering", "influencing", "building trust \& personal accountability", dan "critical \& analytical thinking”. Selanjutnya, dilakukan penyesuaian definisi perilaku dimasing-masing tingkatan, dengan mempertimbangkan kompetensi OHS bagi line function dan mempertimbangkan PT XYZ value behavior. Jumlah tingkatan perilaku diseragamkan menjadi lima sesuai ketentuan dari perusahaan. Kamus kompetensi yang telah diadaptasi tersebut kemudian dijadikan rujukan dalam menentukan tingkat kompetensi bagi masing-masing jabatan di departemen OHS. Sehingga dihasilkan matriks tingkat kompetensi untuk masingmasing posisi.

Analisis terakhir untuk melengkapi model kompetensi tersebut adalah dengan melengkapi program pengembangan untuk masing-masing tingkat kompetensi. Hasil akhir dari matriks kompetensi untuk departemen OHS meliputi daftar kompetensi utama yang dipersyaratkan, definisi masing-masing kompetensi, tingkatan masing-masing kompetensi, pengembangan untuk setiap tingkatan, dan kebutuhan kompetensi untuk setiap posisi jabatan di departemen Corporate OHS.

\section{Saran}

Departemen Corporate OHS disarankan untuk menerapkan model kompetensi yang dibangun dalam penelitian ini sebagai panduan dalam proses pengembangan tim yang sudah ada dan juga proses seleksi karyawan baru. Dengan demikian, diharapkan dapat meningkatkan kinerja departemen tersebut. Meskipun penelitian ini difokuskan pada penyusunan model kompetensiOHS.Namun, metodedanpendekatan yang digunakan juga dapat diterapkan ke area kerja lainnya. Metode modified DACUM dapat dipergunakan 
untuk merumuskan kompetensi di organisasi yang baru dibentuk, dimana tidak ada pembanding antara top performer dengan poor performer. Selain itu metode ini juga sangat membantu untuk organisasi yang proses bisnisnya bersifat unik, dimana tidak bisa langsung diperbandingkan dengan kamus kompetensi umum yang sudah ada. Untuk memastikan proses penerapan dapat berjalan dengan baik maka model kompetensi ini perlu ditindak-lanjuti oleh departemen people development dengan menyusun modul-modul pengembangan dan metode penilaian yang sesuai.

\section{DAFTAR PUSTAKA}

Bashook P. 2005. Best practices for assessing competence and performance of the behavioral health workforce. Administration and Policy in Mental Health 32: 563-592.

Dar I. 2011. Managing human capital for sustainable competitive advantage: a case of ufone gsm Pakistan. Interdisciplinary Journal of Contemporary Research In Business 2(11): 498510.

DeSarboW,BenedettoA, Song M.2007.Aheterogeneous resource based view for exploring relationships between firm performance and capabilities. Journal of Modelling in Management 2(2): 103124.

Dubois D, Rothwell W. 2004. Competency Based Human Resource Management. California, USA: Davies Black Publishing.

Ey P. 2006. A track-by-level approach to performance competency modeling. [dissertation]. California: Faculty of the College of Business Administration of Touro University International.

Fabio B, Hubeis M, Puspitawati H. Pengaruh gaya kepemimpinan, motivasi kerja terhadap komitmen organisasi yang berimplikasi pada kinerja karyawan. Jurnal Aplikasi Bisnis dan Manajemen 2(1): 91-104.

Foon L. 2009. Capabilities differential as source of sustainable competitive advantage. International Journal of Business and Society 10(2): 20-38.

Gangani N, McLean G, Braden R. 2006. A competencybased human resource development strategy. Performance Improvement Quarterly 19(1):127139.

Gilgeous V, Parveen, K. 2001. Core competency requirement for manufacturing. Integrated manufacturing system 12 (3): 217-228.
Goel A, Rana G, Rastogi R. 2010. Knowledge management as a process to develop sustainable competitive advantage. South Asian Journal of Management.17(3): 104-116.

Gupta A. 2012. Sustainable competitive advantage in service operation : an empirical examination. The Journal of Applied Business Research 28(4): 735-742.

Khandekar A, Anuradha S. 2005. Managing human resource capabilities for sustainable competitive advantage, an empirical analysis from indian global organisations. Education \& Training Journal 47(8): 628-639.

Ljungquist U. 2007. Core competency beyond identification: presentation of a model. Management Decision Journal 45(3):393-402.

Marchington M, Caroll M, Boxal, Peter. 2003. Labour scarcity and the survival of small firms. Human Resource Management Journal 13(4):5-22.

McShane S, Glinow M. 2010. Organizational Behavior. New York: McGraw-Hill.

Muslera R, Urquiza A, Cepeda I. 2012. Competencybased model through it: an action research project. Syst Pract Action Res 25: 117-135.

Ponanake P. 2014. Establishing hospital's core competencies with six sigma practices in the asean economic community. The Journal of American Academy of Business 20(1): 114-121.

Sharkie R. 2003. Knowledge creation and it's place in the development of sustainable competitive advantage. Journal of Knowledge Management 7(1): 20-31.

Shippmann J, Ash R, Carr L, Hesketh B. 2000. The practice of competency modelling. Personnel Psychology. 53 (3) : 703-739

Tobin D, Margaret S. 2008. The AMA Guide To Management Development. New York: American Management Association.

Trathen S. 2007. Executive coaching, changes in leadership competencies and learning agility amongst microsoft senior executive. [dissertation]. Colorado: Colorado State University.

Ulrich D, Allen J, Brockbank W. 2009. HR Transformation Building Human Resource from The Outside In. New York: McGraw-Hill.

Yang B, Wu B, Shu P, Yang M. 2006. On establishing the coer competency identifying model: a valueactivity and process oriented approach. Industrial Management + Data Systems 106(1): 60-80. 